\title{
Service life planning for electronics, mechanical and electrical components of a hotel building
}

\author{
Peter F. Kaming ${ }^{1,}$, Desi Maryani ${ }^{2}$, and Michael Boenardi ${ }^{2}$ \\ ${ }^{1}$ Lecturer, Universitas Atma Jaya Yogyakarta, Indonesia \\ ${ }^{2}$ Alumni, Universitas Atma Jaya Yogyakarta, Indonesia
}

\begin{abstract}
A hotel building in Yogyakarta was studied for its service life planning of electronic, electrical, and mechanical components the building. The study aims to assess the service life of hotel buildings including its electronics, mechanical and electrical components, and estimating the service life of each of the components. Data was collected from practitioners working in building maintenance office of several hotels in Yogyakarta. The Data was carefully analysed using descriptive statistics. This paper discusses the approaches and application of the availability of reference service life and service period data can be collected and applied in life cycle costing. The results of service-life data for periodical maintenance and replacement for various electronics, both mechanical and electrical parts are also presented for life cycle planning.
\end{abstract}

\section{Introduction}

Service life is quite crucial in the developmental stages of buildings and infrastructures. During the feasibility stage, the service life usually assessed for investment decision, the longer service life is the better but less economical because more money will be spent on the initial investment cost since a higher eminence costs more. If the initial cost spent for designing a good quality is high, the maintenance cost spent should be less throughout the use of the appliance. In the designing stage, service life is quite helpful for creating a valid decision policy that can be implemented to improve status quo. Evaluating the quality of materials and the workmanship available for construction is vital to quality and workmanship should be stated in the specification for a building. To fulfill the requirements set by the designer during construction, the constructor has to comply with specification and rely on the competence of his workers for the construction of the building. In the operational stage of the building, service life is useful for maintenance activities. Besides the service life of the components for replacement, service period data is needed for the building components are needed for the building to function adequately. [1]

During the operational stage, the data of service life and service period for a component of a building is very vital. Even in the design stage, particularly when the building cost is analyzed using life cycle costing concept, these data cannot be absent. Both the architect and civil engineer can propose a longer durable building component to last more and reduce

* Corresponding author: kaming@mail.uajy.ac.id 
the service interval period. As Hovde and Moser [1] pointed out, over the past decade, there had been an ever-increasing focus on the needs to determine the durability and service life of materials, components, installations, structures and buildings. There had been based on two important aspects:

1) Environmental issues - scarcity of energy, material, and resources affects the building \& construction sector as a big consumer of these resources, and the environmental impact caused by buildings.

2) Economic issues - The total value of the depleted environment on a national level and the value of the buildings for owners such as government or private individuals. The conditions of the damaged environment, the annual costs of management and maintenance and the life-cycle costs such as hotel buildings were of major importance for both the tourism sector of the economy and maintaining competitiveness within an industry or corporation.

By adopting a methodology for service life planning of building components and materials described by [2], this study aims at;

1) Collecting service life data for the electronic and mechanical (E \& ME) components of the hotel building;

2) Finding out the service maintenance interval (service period) of the $E \& \mathrm{ME}$ components of the building. The reason the electronic and mechanical components are studied is because they are costly and require more frequent service interval and are relatively short in service life compared other building components.

\section{Literature reviews}

\subsection{Availability of data in the industry}

An ideal situation is that the data is well defined, accurate, and available in all three aspects. However, this is not always the situation today; very few service-life data are available. Data at hand will be used in estimations although they may not be as accurate as desired. This is accepted in the project and this shortage will be used to point out further research. Results of estimations are shown as examples.

It is essential to describe the function and the requirements of every component of the building since the service life of a component is reached when these requirements are not met. The same approach applies to all parts of the building such as structure, building envelope, services, compliments etc. When establishing the requirements of a component, it is essential to define the level of the component based on its description [1].

\subsection{Service life of building components}

\subsubsection{Service life changes in condition over-time}

The ability to quantify changes in condition over time is important to ensure a sustainable development in the created environment, whilst Factor Method [ISO 15686-1:2008] [3]. For the service life prediction calculated, the estimated service life was not the changes in condition [4]. The study looked at the application of neuro-fuzzy artificial intelligence to translate expert knowledge into probability values to supplement historic performance data for the development of Markovian transitional probability matrices, towards prediction of service life, changes in condition over time, and the effects of maintenance levels on the service life of buildings. 


\subsubsection{Use of service life for $L C A$}

A study based on the need of service life data in LCA, the way the data is developed and how it influences the result stated during that time horizon in Life Cycle Assessment (LCA) depends on the product being studied and on the goal definition of the LCA [5]. Service Life Prediction is the prediction of service life under specific conditions, as found in service life models or testing. Wooden cladding and brick veneer are the external wall materials included in the study. There is a large variation in the environmental load calculated from LCA for the different scenarios. Result of the study showed that in order to use LCA as a tool to evaluate the environmental quality of different products, it is important to assess the surroundings where the materials were used, and the maintenance of the materials throughout use.

\subsubsection{Service life prediction model}

Githachuri el al described a study that examined and compared the potential durability performance of various geographically distinct South African marine concrete mix types [6]. Mix proportions were designed at two water/binder ratios $(0.40$ and 0.55$)$ for different material combinations of binder and aggregate types. Sampling was done at 28, 91, and 182 days. Durability performance was inferred from a durability index (DI) test that measures the resistance of the concrete to ion, gas, and fluid penetration. Comparison was made on the basis of the regional concrete type, $\mathrm{w} / \mathrm{b}$ ratio and mix constituents (binder and aggregate type). All the concrete mixes were further compared to plain CEM I control concrete mixes at each $\mathrm{w} / \mathrm{b}$ ratio. Results indicate that low $\mathrm{w} / \mathrm{b}$ ratio and blended binder concrete mixes have low penetrability features. The aggregate type was seen not to have an appreciable influence on the transport properties of concrete. Across the range of geographically different mixes, it was found that with a given concrete grade and binder type, marine concrete mixes are practically comparable. This permits the existing service life prediction model to be more confidently applied for all marine zones in South Africa with possible application in other geographic regions following further research.

\subsubsection{Service life prediction using simulation techniques}

Akiyama et.al. explored the importance of considering long term performances in the design of reinforced concrete (RC) structures in a marine environment and how to consider the effects of this environment on the long-term performance structurally [7]. The study proposed a time-dependent structural reliability analysis method and considered the hazards associated with airborne chlorides. Also it indicated a procedure to obtain the failure probabilities of RC structures in marine environments updated by Sequential Monte Carlo Simulation (SMCS). In the procedure mentioned in the study, the corrosion crack width was used as an observational data. For illustrative purposes, time-dependent reliability analyses are presented for one-way RC slabs in a marine environment. Using SMCS, multiple random variables related to observation information can be updated simultaneously.

\subsubsection{Service life estimation using factor method}

Marteinsson presented a discussion on service life planning and the role of the Factor Method in such work and the discussion based on the modification and development of the methodology [8]. In the design process, according to Marteinsson, the need to evaluate the service life of products posed a great challenge, as the results would depend on both 
material properties and the environment in which the material was placed or used. He further added that a practical solution had to be based on a good knowledge in the field and a sound working strategy to ensure different design scenarios could be compared in a standardized or structured way. He also suggested the Factor Method as a promising working tool for such an evaluation and comparison. The use of this methodology was limited, and as such, is discussed a lot by researchers. However, its future will depend upon how practical its application is in use.

\subsubsection{Relationship between maintenance interval and performance}

Au-Yong et.al carried out a study aimed at analyzing the relationship between length of predetermined maintenance interval and maintenance performance [9]. The literature review identified the length of a predetermined maintenance interval as an importance feature of a scheduled maintenance strategy. A quantitative approach was adopted and carried out through a questionnaire survey. Subsequently, descriptive analysis and correlation analysis were used to analyze the collected data. The result of the study with the associative test revealed that there were significant correlations between the length of predetermined maintenance interval and maintenance performance. Inappropriate maintenance interval led to an expensive i impact in maintenance management. Therefore, the importance of predetermined maintenance interval should be taken into consideration in the maintenance organization. Accurate maintenance interval was likely to optimize the maintenance outcome and curb the expenditure. The study also suggested the maintenance management to carry out continuous monitoring or regular inspection towards the building systems and components.

\subsubsection{Service life for electronic equipment}

Li et.al studied the service life of electronic equipments in the hot and humid southeast coastal areas with high salinity. [10] The paper analyzed the characteristics of electronic equipment, as well as the impact of high temperature, humidity, and high salinity on electronic equipment using a neural network method to establish these events. Results of the study showed that the predicted life of the equipment at a specific temperature and humidity could be a basis for preventive maintenance. The method can be workable, and provide an effective solution to the problem of equipment life in areas of high temperature, high salinity and humidity.

\section{Methodology}

\subsection{Data collections}

The data of service life and service period were collected from three persons (one manager and two staff in building maintenance office). They were currently in charge of the hotel at that time but previously engaged in other four stars hotel in Yogyakarta. The other three persons were building managers working in other hotels, but they were engaged because the same hotel groups had international chains. The other personalities of the respondents were available in these reports. [11-12] The respondents were visited at appointments since they were busy professionals and had supervision jobs at their hotels. The respondents were asked for the service life and service period on experience basis. A list of areas including electronics, mechanical, and electrical parts were presented and data requested the regarding service life and service period. 


\subsection{Methods for determining the service life and service period.}

The formula was interpreted to mean that the methodology was purely deterministic and it is generally accepted that degradation processes are of a highly stochastic nature. The main topics of the discussion have been:

(i) The method is too simple and unreliable

(ii) Factors are difficult to estimate and uncertainty in results will therefore be great

(iii) The method is deterministic and cannot be used in a reliability-based design.

These topics are discussed. [13-14] The discussion has certainly been of keen interest for the evaluation of the method. The point regarding the method necessarily being deterministic is somewhat astonishing as is clearly stated in the ISO 15686-1 (ISO 2008) [4].

\subsection{The building under studied}

The hotel building is situated in the business area of Sleman District in Yogyakarta with a slot of $3735 \mathrm{~m}^{2}$, and floor area of $22118 \mathrm{~m}^{2}$. The building consists of 2 basements, 8 floors, and is used mainly as a daily stay for visitors and also has facilities for meetings and conference with a limited number of occupants. The hotel project started in December 2016, and expected to be concluded within a year. The building is a four-star hotel with hotel rooms situated from the fourth floor and from the ground up to the third floor is meant for retails. The hotel also owns a 5-floored parking building at the back of the hotel. The hotel is considered as a new identity that truly represents beauty and an elegant architecture yet still conserving nature and embracing culture, a symbol of dignity and prosperity that represents its top notch hotel services and ultimate luxury.

\section{Results and discussion}

\subsection{Data collection}

Distributing of the questionnaires was conducted to determine service life of components of the building materials used in the hotel building constructions. From 11 people who responded to the questionnaire, an average service life and testimony of building materials used in the construction of buildings was obtained. Table 1 below will explain the average service life from the respondent based on their experiences regarding the replacement period of the building components and testimony of building materials or equipment of the producers.

\subsection{Service period of building component}

Data of periodical services obtained from 6 building practitioners could be used either by mean or mode depending on the present risk consideration. For example for the elevator, the service maintenance period can apply mean. In practical sense, it would be round off to 0.5 meaning that twice a year, expenses are made for oiling or cleaning the elevator. If no mode was obtained, mean can be applied to the maintenance period considering the practicality and use of a round value. For example, safety valve has a mean of 0.94 , so it is applied once in a year throughout the service period. For the indoor hydrant box, the mean value was applied because of the large data range to wisely round if off to once a year for service maintenance. Note that the bold numbers are applied for calculation of cost component based on those service periods. See Table 1. 
Table 1. Periodical services for some building components [10] and [11].

\begin{tabular}{|c|c|c|c|c|c|c|c|c|c|c|c|c|c|}
\hline \multirow{2}{*}{$\begin{array}{c}\text { Building } \\
\text { Component }\end{array}$} & \multicolumn{13}{|c|}{ Periodical Service (years) } \\
\hline & 1 & 2 & 3 & 4 & 5 & 6 & 7 & 8 & 9 & 10 & 11 & mean & mode \\
\hline \multicolumn{14}{|c|}{ Transport Equipment } \\
\hline Elevator & 1.00 & 0.25 & 1.00 & 0.08 & 0.08 & 0.08 & 0.25 & 0.25 & 1 & 0.08 & 0.08 & 0.377 & 0.08 \\
\hline \multicolumn{14}{|l|}{ Air Condition } \\
\hline Panel Unit & & 0.50 & 1.00 & 0.50 & 0.08 & 0.25 & 1 & 0.5 & 0.5 & 0.5 & 0.5 & 0.533 & 0.5 \\
\hline Chiller & & 0.50 & 1.00 & 0.50 & 0.08 & 0.25 & & 0.5 & 1 & 0.5 & 1 & 0.592 & 0.5 \\
\hline $\begin{array}{l}\text { Cooling } \\
\text { Tower }\end{array}$ & & 0.50 & 1.00 & 0.50 & 0.08 & 0.25 & 0.25 & 0.5 & 0.5 & 0.5 & 0.5 & 0.458 & 0.5 \\
\hline Pump & & 0.50 & 1.00 & 0.50 & 0.08 & 0.25 & & 1 & 0.5 & 1 & 0.5 & 0.592 & 0.5 \\
\hline Tank & & 0.50 & 1.00 & 0.50 & 0.08 & 0.25 & & 0.5 & 1 & 0.5 & 1 & 0.592 & 0.5 \\
\hline $\begin{array}{l}\text { Chemical } \\
\text { Unit }\end{array}$ & & 0.50 & 1.00 & 0.50 & 0.08 & 0.25 & 0.25 & 0.5 & 0.5 & 0.5 & 0.5 & 0.458 & 0.5 \\
\hline AHU Unit & & 0.50 & 1.00 & 0.50 & 0.08 & 0.25 & 0.25 & 0.5 & 0.5 & 0.5 & 0.5 & 0.458 & 0.5 \\
\hline FCU Unit & & 0.50 & 1.00 & 0.50 & 0.08 & 0.25 & 0.25 & 0.5 & 0.5 & 0.5 & 0.5 & 0.458 & 0.5 \\
\hline Fan & & 0.50 & 1.00 & 0.50 & 0.08 & 0.25 & 0.25 & 0.5 & 0.5 & 0.5 & 0.5 & 0.458 & 0.5 \\
\hline $\begin{array}{l}\text { Accessories } \\
\& \text { Valve }\end{array}$ & & 0.50 & 1.00 & 0.50 & 0.08 & 0.25 & 0.25 & 0.5 & 0.5 & 0.5 & 0.5 & 0.458 & 0.5 \\
\hline Ducting & & 0.50 & 1.00 & 0.50 & 0.08 & 0.25 & 0.25 & 0.5 & 0.5 & 0.5 & 0.5 & 0.458 & 0.5 \\
\hline Air Regist & & 0.50 & 1.00 & 0.50 & 0.08 & 0.25 & 0.25 & 0.5 & 0.5 & 0.5 & 0.5 & 0.458 & 0.5 \\
\hline Cabling & & 0.50 & 1.00 & 0.50 & 0.08 & 0.25 & 0.25 & 0.5 & 0.5 & 0.5 & 0.5 & 0.592 & 0.5 \\
\hline Chiller Pipe & & & 1.00 & 1.00 & 0.08 & 1.00 & 0.25 & 0.5 & 0.5 & 0.5 & 0.5 & 0.592 & 1 \\
\hline Condenser & & & 1.00 & 1.00 & 0.08 & 1.00 & 0.25 & 0.5 & 0.5 & 0.5 & 0.5 & 0.592 & 1 \\
\hline $\begin{array}{l}\text { Drain Pipe } \\
\text { PVC }\end{array}$ & & & 1.00 & 1.00 & 0.08 & 1.00 & 0.25 & 0.5 & 0.5 & 0.5 & 0.5 & 0.592 & 0.5 \\
\hline \multicolumn{14}{|c|}{ Fire Extinguisher } \\
\hline $\begin{array}{l}\text { Joekey } \\
\text { Pump }\end{array}$ & 1.00 & 1.00 & 2.00 & 0.25 & 0.25 & 1.00 & 0.5 & 1 & 1 & 0.5 & 0.5 & 0.818 & 1 \\
\hline $\begin{array}{l}\text { Electric } \\
\text { Pump }\end{array}$ & 1.00 & 1.00 & 2.00 & 0.25 & 0.25 & 1.00 & 0.5 & 1 & 1 & 0.5 & 0.5 & 0.818 & 1 \\
\hline $\begin{array}{l}\text { Diesel } \\
\text { Pump }\end{array}$ & 1.00 & 0.50 & 1.00 & 0.25 & 0.25 & & 0.5 & 1 & 1 & 0.5 & 0.5 & 0.65 & 1 \\
\hline $\begin{array}{l}\text { Indoor } \\
\text { Hydrant } \\
\text { Box }\end{array}$ & 2.00 & 1.00 & 3.00 & 0.50 & 0.25 & 0.25 & 1 & 2 & 2 & 0.5 & 0.25 & 1.159 & 2 \\
\hline $\begin{array}{l}\text { Outdoor } \\
\text { Hydrant } \\
\text { Box }\end{array}$ & 2.00 & 1.00 & 3.00 & 0.50 & 0.25 & 0.25 & 1 & 2 & 2 & 0.5 & 0.25 & 1.159 & 2 \\
\hline $\begin{array}{l}\text { Hydrant } \\
\text { Pylor }\end{array}$ & 2.00 & 1.00 & 4.00 & 0.50 & 0.25 & 0.50 & 1 & 2 & 2 & 0.5 & 0.25 & 1.272 & 2 \\
\hline $\begin{array}{l}\text { Siamese } \\
\text { Connection }\end{array}$ & & 2.00 & & 0.50 & 0.25 & 1.00 & 1 & & 2 & 0.5 & 0.25 & 0.937 & 0.5 \\
\hline Gate Valve & & 2.00 & 2.00 & 0.50 & 0.25 & 1.00 & 1 & & 2 & 0.5 & 0.25 & 1.055 & 2 \\
\hline Check Valve & & 2.00 & 3.00 & 0.50 & 0.25 & 1.00 & 1 & 2 & 2 & & 0.25 & 1.333 & 2 \\
\hline "Y" Strainer & 1.00 & 2.00 & 1.00 & 0.50 & 0.25 & 1.00 & 1 & 2 & 2 & & 0.25 & 1.1 & 1 \\
\hline Safety Valve & & 2.00 & & 0.50 & 0.25 & 1.00 & 1 & 2 & 2 & & 0.25 & 1.125 & 2 \\
\hline
\end{tabular}

Regarding the Maintenance period of the building components in Universitas Negeri Malang (UM): The elevator service period is $\leq 1$ month; Clean and waste water installation, air conditioning system, telephone, and internet ranges between 1 to 6 months; Sanitary equipment, electrical installation, and CCTV falls between 6 months to 1 year; the Plastering, wall ceramics, floor ceramics, fire protection, wall paintings, door and window paintings, exit ways, lightning protection, and ceilings are between 1 to 5 years; and the Wall and roof construction \& Materials are $\geq 5$ years. [15] 


\subsection{Service life prediction}

Table 2 and 3 showed the service life for some building components obtained from the survey from this study. Note that similar principles were applied to determine the service life, either by mean or mode could be used for calculating cost in each component for the replacement period.

Table 2. Examples of periodical service and service life of the equipment component.

\begin{tabular}{|c|c|c|c|}
\hline Component of Building & $\begin{array}{l}\text { Period Service } \\
\text { (month) }\end{array}$ & $\begin{array}{l}\text { Service Life } \\
\text { (year) }\end{array}$ & Brand \\
\hline \multicolumn{4}{|l|}{ Transportation Equipment } \\
\hline Elevator & 2 & 21 & Schindler \\
\hline \multicolumn{4}{|c|}{ Air Condition and Supporting Accessories } \\
\hline Panel Unit & 6 & 8 & SPLN \\
\hline Chiller & 6 & 8 & Bosch \\
\hline Cooling Tower & 6 & 8 & Shinwa \\
\hline Pump & 6 & 8 & Mitsubishi \\
\hline Tank & 6 & 8 & Tda 1200 \\
\hline Chemical Unit & 6 & 8 & Tda 1200 \\
\hline AHU Unit & 6 & 8 & Mitsubishi \\
\hline FCU Unit & 6 & 8 & Mitsubishi \\
\hline Fan & 6 & 8 & Nicotra \\
\hline Accessories \& Valve & 6 & 8 & Toyo \\
\hline Ducting & 6 & 8 & Lokfom \\
\hline Air Register & 6 & 8 & Toshiba \\
\hline Cabling & 6 & 8 & Supreme \\
\hline Tray Cable & 6 & 8 & Duta Listrik \\
\hline Chiller Pipe & 12 & 8 & Denji \\
\hline Condenser Pipe & 12 & 8 & Denji \\
\hline Drain Pipe PVC & 12 & 8 & Wavin \\
\hline \multicolumn{4}{|l|}{ Electrical } \\
\hline Feeder Cable \& Installation & 24 & 15 & Supreme \\
\hline Fire Proof Cable & 24 & 13 & Pirelli \\
\hline Cable Ladder/ Tray & 36 & 17 & Duta Listrik \\
\hline $\begin{array}{ll}\text { PVC Conduit } & \text { Fire } \\
\text { Reterdant } & \end{array}$ & 24 & 8 & EGA \\
\hline Electric Socket & 12 & 7 & Schneider \\
\hline Lamp & 12 & 2 & Philips \\
\hline $\begin{array}{l}\text { Inbow Doos Electric } \\
\text { Socket }\end{array}$ & 24 & 12 & Boss \\
\hline Capasitor Bank & 12 & 11 & GAE \\
\hline Timer Switch & 12 & 2 & Omron \\
\hline Lightning Rod & 12 & 15 & Prevectron \\
\hline \multicolumn{4}{|l|}{ Transformator Installation } \\
\hline Transformator (Dry Type) & 12 & 18 & Bambang Djaya* \\
\hline \multicolumn{4}{|l|}{ Fire Alarm system Installation } \\
\hline Device & 12 & 10 & Notifier \\
\hline Cable & 12 & 12 & Supreme \\
\hline Fire-proof Cable & 24 & 15 & Pirelli \\
\hline
\end{tabular}


Table 3. Examples of periodical service and service life of the electronics component.

\begin{tabular}{|l|c|l|l|}
\hline \multicolumn{1}{|c|}{ Component of Building } & $\begin{array}{c}\text { Period Service } \\
\text { (month) }\end{array}$ & $\begin{array}{c}\text { Service Life } \\
\text { (year) }\end{array}$ & Brand \\
\hline Sound System & 12 & 8 & TOA \\
\hline Device & 24 & 12 & Supreme \\
\hline Cable & 36 & 17 & Pirelli \\
\hline Fire-Proof Cable & 36 & 17 & Duta Listrik* \\
\hline Tray Cable & 12 & 3 & Vektor \\
\hline UPS & 12 & 12 & Transtel \\
\hline PABX \& Telephone & 12 & 4 & Schneider \\
\hline Outlet Telephone & 12 & 11 & LSA \\
\hline Terminal Telephone & 12 & 5 & Belden \\
\hline Data Cable UTP & 12 & 6 & Schneider \\
\hline Outlet Data & 12 & 6 & Supreme \\
\hline Telephone Cable & 12 & 10 & HP \\
\hline Patch Panel \& Accessories & 12 & 9 & HP \\
\hline Switch & 12 & 11 & HP \\
\hline Rack Patch Panel & 12 & 7 & Pensil \\
\hline CCTV System & 12 & 8 & Supreme \\
\hline CCTV Equipment & 12 & 7 & Belden \\
\hline Cable Power & \multicolumn{5}{|l|}{} \\
\hline Cable Data UTP & 6 & 4 & Ikusi \\
\hline Installating System MATV & 12 & 6 & Belden \\
\hline MATV Equipment & 24 & 5 & EGA \\
\hline Cable & 12 & 5 & Schneider \\
\hline Conduit PVC & \multicolumn{5}{|l|}{} \\
\hline Outlet & \multicolumn{5}{|l|}{} \\
\hline
\end{tabular}

\section{Conclusions and recommendation}

The service life used in this study was gathered from stakeholders involved in the suppliers, consultants, and academics in the construction industry, as well as the maintenance officers and operation managers from the other hotels who had some drawbacks in terms of its quality and quantity. This study provided the following recommendations and perhaps similar information should be gathered for more accuracy based on the empirical research methodology.

The service life and service period of the electronic, mechanical and electrical components obtained from this study was subjective and mostly relied on the experience of professionals available to identify the service life components of the hotel. However, the researched data can be useful for maintenance planning purposes of the hotel on short ( 5 years) and long term (25 years) range and not limited to the whole life cycle as suggested [16]. The service period and service life could also be adjusted when the factors related to the degradation of the use and components exposed to the environment were recognized as suggested by ISO in the 15865 -Part 1 . The product of this study regarding service life and periodical maintenance can be applied profitably for implementing a future maintenance plan.[17] In future, researches should emphasize more on service life for buildings and the infrastructure components for local conditions adopting the factor methods of ISO 15686 part 1 on ASTM G166, ASTM G172 that provides guidance to estimate service life of products when an adequate sample size has been obtained through testing, either under normal conditions, or in an accelerated test setup. The Recommendation of RILEM TC 190-SBJ: service-life prediction Recommendation of RILEM TC 190-SBJ. [18] ASTM 
G166 and ASTM G172, service-life prediction and creating specific WLCC research models for more types of buildings and civil engineering projects in developing countries.

This research is internally funded by Universitas Atma Jaya Yogyakarta (UAJY). The author is grateful to the Research and Service Boards of UAJY, building officers of the hotels, suppliers, and all consultants who participated in this study. The author is also thankful to reviewers for their candid comments and critics for quality improvement of this paper.

\section{References}

1. P. J. Hovde and K. Moser, CIB W080 / RILEM 175 - SLM: Service Life Methodologies, State of the Art Reports (2004)

2. G. Hed, Licentiate thesis, Kungl. Tekniska Högskolan RD-report No 4, Stockholm, Sweden (2000)

3. Duling, J.M, Horak, E. and Cloete, C. ISTANBUL - TURKEY May 11-14th, (2008)

4. ISO 15686-1, Geneva (2000).

5. S.M. Strand and P.J. Hovde, Ottawa On, K1a 0r6, National Research Council Canada (1999).

6. K. Githachuri, M. Alexander, and P Moyo, Materials and Structures 45:185-198, DOI 10.1617/s11527-011-9759-0 (2012)

7. M. Akiyama, D.M Frangopol, I. Yoshida, H, Tsuruta, and T, Shimomura, Modelling of Corroding Concrete Structures, 273 RILEM Bookseries 5, DOI 10.1007/978-94-0070677-4_19, C RILEM (2011)

8. A. Marteinsson, KTH Research School Department of Technology and Built Centre for Built Environment Environment, University of Gävle. (2005)

9. C.P. Au-Yong, A.S. Ali, F. Ahmad, Applied Mechanics and Materials ISSN: 16627482, Vol. 845, pp 305-310, doi:10.4028/ www.scientific.net/AMM.845.326 (C) Trans Tech Publications, Switzerland. (2016)

10. X. Li, Z. Yang, Z Pang, Y Liu, H. Wei and J. Luo, Proceedings of the 15th International Conference on Man-Machine-Environment System Engineering, Lecture Notes in Electrical Engineering 356, DOI 10.1007/978-3-662-48224-7_70@ Springer-Verlag Berlin Heidelberg, (2015)

11. D. Maryani, Final Report, Faculty of Engineering, Universitas Atma Jaya Yogyakarta, in Bahasa (2017).

12. M. Boenardi, Final Report Faculty of Engineering, Universitas Atma Jaya Yogyakarta in Bahasa (2018).

13. Strand, S.M and Hovde, P.J, Ottawa ON, K1A 0R6, Canada, pp. 1948-1958. National Research Council Canada. (1999)

14. L. O. Madrigal, J. M. F. Bretones, and B. S, Journal of Construction, 14 (1) 60-68 (2015)

15. A.M. Hajji, A. Suharsono. A Study on the Characteristics of Building Maintenance on Public Universities in Malang City,

16. R. Flanagan, \& C. Jewell, Oxford: Blackwell Publishing Ltd. (2005).

17. P.F.Kaming and J. Mardiansyah, Applied Mechanics and Materials ISSN: 1662-7482, Trans Tech Publications, Switzerland. Vol. 845, pp 326-331, doi:10.4028/www.scientific.net/AMM.845.326 (C) (2016). 
18. Lacasse, M.A. and Sjöström, C. (2004), Proceedings of the CIB World Building Congress 2004 - Conference on Research and Innovation (Toronto, Ontario, 5/2/2004), pp. 1-9, May 01, (NRCC-47030). (2004) 